ANNA ŁOŚ-TOMIAK

\title{
Intersectoral cooperation \\ as a basis for social \\ security
}

\section{Introduction}

The realization of individual and social needs requires the production and efficient distribution of different kinds of goods and services. The task more difficult, the more niche is the social issue, the smaller group of beneficiaries and the more expensive process of goods and service production, as well as a disproportionally low rate of return on the investment. The existing socio-economic conditions of particular states, including Poland, and also global conditions, do not allow to satisfy all various needs and elimination of social issues concerning some communities or groups. It is also not possible for particular participants of the market not to cooperate in the area of production, distribution and consumption. Moreover, there has been a change of the manner of defining particular entities and their mutual relations. Both, public institutions, commercial enterprises and non-governmental organizations become market participants based on equal rights.

The aim of the paper is to present substantive, organizational and financial interdependence between sectors of the economy, first of all

Ph.D. Anna Łoś-Tomiak University of Zielona Gora to define the relationships existing between non-governmental organizations and public institutions. It is also to determine the 
advantages and benefits from cooperation, both, for the particular executors of tasks and beneficiaries, who, due to the cooperation of entities, obtain a better product.

\section{Separation of the economy: public, market and non-governmental sector}

Treating the government and state entities that realize public goals from public money as the first sector and the market with the entities that for finalizing private projects use private capital, as the second sector, it should be possible to define non-governmental organizations of a private nature, acting for the public good, as the third sector (Marciniak 1998, p. 39).

Public sector is formed by non-profit organizations, which finance their all expenditure from the state budget or the local government budget. It is the public administration, defined also as the state sector. The main task of these entities is planning, implementing and financing the redistribution of income, which is based on well-established, recognized criteria. The principles, however, the organizations and institutions of this group are governed by, are egalitarianism and safety.

The second sector includes private organizations, which are profit-oriented, that cover their expenses from private capital. It is the sphere of business, that is all institutions and organizations whose activity is directed to developing a financial surplus. It is called a market sector, where the rule of operation is to minimize cost and gain profit. The organizations operating in it satisfy, through production, first of all material needs that are expressed in money.

The sector located between them is the non-governmental sector. It embraces the entities that finance their all expenses from both, the state budget and using private or citizenship capital. It is the whole of private organizations, acting socially and not for profit, that is non-profit organizations. The basis of the third sector institutions are individual and real human needs, and the priority of their operation is common and social solidarity (cf. Schimanek 1997, p. 37; Krzyżanowska 2000, p. 2)

Non-governmental actors are located between institutions of the public sector that is created by, among others, public healthcare system, local authorities and central authorities, as well as of the private sector, which includes commercial companies, people running business activities and individuals. Relevant organizations of the third sector are charities, voluntary organizations, lobbying, subsidized artistic institutions, churches, trade unison, employers' associations, professional associations, clubs. There are also institutions difficult to include 
explicitly in one of these groups. The organizations at the interface of the third and public sector refer to housing associations, professional higher schools, teacher training college, schools maintained with donations or museums. However, the area between the non-governmental and private sector can be completed by independent schools, cooperatives, mutual insurance societies and mutual benefit associations (Hudson 1997, p. 21).

\section{Relations between sectors}

The coexistence and partner cooperation of the entities of state, market and civic institutions in the market economy is extremely significant. It has special importance for establishing lasting and sustainable development, achieving social welfare and satisfying social needs at the expected level, with using available, complementary potentials. "The third sector collaboration with other sectors and social entities strengthens all social segments included in the cooperation process and the social system as a whole. It contributes to the better, more effective functioning of a commune, ministry, local newspaper, company, and finally - the institution of the state, which due to that cooperation becomes simply better and more efficient, more stable and resistant to crises, more effectively satisfying needs of its citizens" (Glinski 1998, p. 51). What is more, for many institutions, which are different in terms of a legal and organizational form, manner of financing actions, or fiscal duties, it is appropriate to be governed by the common good, to focus on higher values, on human needs and gaining the high utility from the consumption of goods and services (Kafel 1997, p. 83). Moreover, which is not meaningless, many of them perceive cooperation and collaboration to be the way to obtain benefits and realize individual goals.

Nowadays it is popular to state that the optimal safety of citizens requires a tight cooperation, based on agreement and respect of all social and economic entities, although not long ago the relations between public administration, market and the third sector were based on competition, or even mutual unwillingness, and if there was cooperation, it was not legally authorized (Leś 1998, p. 52-53). The share of business institutions in the market of social services was not well developed either, besides, only a small group of customers was catered for. It was difficult to observe a complementary action for particular groups of the recipients of services that were provided by the entities of public and nongovernmental sector, which is not the best certificate for those institutions as well as the direction of the socio-economic policy run by the government.

$x \times$

ANNA ŁOŚ-TOMIAK 


\section{Non-governmental organizations in the implementation of the social function of the state}

The share of non-governmental organizations in the social system depends to a great extent on the accepted model of the implementation of the state social function, on the selection of the direction of the social policy, or on the determination of the communication channels and cooperation of public administration bodies with the third sector institutions. However, the scale of social tasks implemented by government and local government administration, including the share of non-governmental sector, and the nature of mutual relations of entities aspiring to achieve the social welfare and development, is affected by a socio-economic institution, which is closely related to the political profile of elites in power, to their interpretation of the role of the state and the role of a market mechanism in ensuring the growth and economic development as well as the importance of the social policy. Thus, the political system closely defines the shape and character of non-governmental organizations as "the relations that are established between the state - local government - non-governmental sector affect the role and importance of this type of organizations in political activities and in the social sphere" (Kantyka 2002, p. 201).

The practice activities show numerous benefits resulting from the cooperation of the state and non-governmental institutions' sector. Due to it the distribution of goods is more efficient and more effective. It allows to satisfy the needs of a bigger group of customers, creates the possibility of a more economic expenditure of financial resources and increases the chances to implement new techniques or kinds of provided services through more flexible and less dependent from the budget financing the third sector organizations. Due to the division of duties and tasks, mainly related to the social sphere of the state, between non-profit institutions and public organizations, the responsibility connected with solving social issues or taking care of the development of particular regions, branches or situations, is also subject to diversification (Kantyka 2002, p. 52-53).

Acknowledging the share of associations and foundations, or other forms of social organizations, as equal and the same efficient entities in the system of implementing social services is guaranteed by the law. Local administration bodies of the state are required to cooperate with the third sector, having clearly defined the areas of this collaboration and the manner of financing actions. Social entities are considered to be one of the levels occupied with executing public tasks, which is consistent with the constitutional principle of subsidiary, 
and is connected with transferring financial resources for this purpose. The implemented category of the public benefit organization, determining some entities operating in the social sphere, gives priority to non-governmental institutions of this status over other entities of all sectors of the market economy in the implementation of social tasks and entitles them to use public financial resources.

The interaction of public and non-governmental entities brings benefits to not only beneficiaries and the state, as the basic executor of social services, but also to non-governmental organizations themselves. Through the fact of recognition of particular non-profit organizations as the most appropriate to carry out tasks in a range, which is connected with contracting benefits, they gain financial stabilization and the position equal to local government agendas on the market of social services.

At the same time, the recognition of the third sector institutions as equal providers of social services restricts the role of public institutions in providing them, which leads to "non-state" status of the social policy (Rymsza 2001a, p. 4950) and therefore increasing its efficiency. The need to build a real cooperation with social organizations, including delegating tasks, so far located in the structure of public administration and contracting services, mainly oriented to the development of regions and supporting the population, was internalized by both, the representatives of local governments and non-governmental organizations (Boczoń 2001b, p. 77-78)

The socio-economic development depends to a large extent on establishing partner relations between different social entities, including between nongovernmental organizations and local government structures as well as the interaction with the market. It is possible to distinguish two scenarios of the structural inclusion of social entities in executing public tasks (Rymsza 2001b, p. 48-49). The first one, called the nationalization scenario, assumes that social entities should be the next link in the system of transferring public tasks and their "top-down" financing, with the privileged position towards other actors, those having the status of public benefit, that is executing actions within public tasks. The licensing resulting from the scenario would cause the emergence of the network of the social benefit organizations, which would choose such areas of actions that would match the range of tasks ordered by public administration, due to which they would become similar to local government agendas. Such a solution would undoubtedly "facilitate "functional privatization" of the social sphere, but would distort the idea of the development of the civil society" (Rymsza 2001a, p. 50-51). The second one, however, it is a scenario

$x x$

ANNA ŁOŚ-TOMIAK 
of commercialization that assumes the equality of all social and commercial entities in the access to public resources, which can provoke competition, and thus improve the process of implementing public tasks and the increase of their quality, it can however also contribute to marginalize other forms of supporting non-governmental organizations and blur the line between them and business entities. The local government is here the disposer of public resources, which chooses service providers through a tender. Non-governmental organizations assimilate here to the market actors acting according to not for profit principles, which means that they begin to look for profit with the assumption that it will be used for statutory purposes. Both presented scenarios limit a social nature of non-governmental organizations. It is necessary to search for an optimal solution between them. The law on public benefit activity and voluntarism equalled the rights of social entities defining the possibilities of participation in public resources through executing public tasks, it also introduced the notion of a public benefit organization and privileged this type of entities among the others. The forced situation and responsibilities of the sector, the cooperation of the state with non-governmental organizations is proved by the increasing share of financing from public resources, although, as the organizations themselves assess, it is still insufficient, which results from the fact of undertaking by the third sector a range of tasks outsourced by the public administration, particularly in such branches as widely defined social, health, educational or cultural policy. The basis of such an action of the state administration, as well as local government administration is the principle of subsidiary, which allows for the least expensive, fast and effective execution of tasks, due to delegating this responsibility as low as possible, mainly in hands of local leaders of social organizations and initiatives, as anyone who can recognize problems in their own environment and give help where it is mostly needed.

Cooperation in the social sphere of the local government bodies with the third sector institutions is not sometimes systemically consistent, is not based on a proper recognition of needs and problems as well as substantive and economic potential of entities aspiring to take actions in a particular area. Often "each entity acts according to own norms and decides individually what is the most important to satisfy the needs of local community" (Boczon 2001a, p. 163). And it should be otherwise. It would be advisable to define, precisely and mutually, with the use of information possessed by social entities, which, being closest to customers, recognize their needs best, current and long-term goals as well as methods and measures proper for implementing them. In social activities 
of both groups of entities there is no contradiction. For both, local government bodies and non-profit organizations it is important to develop the social good, development of regions, or the elimination of existing issues. However, their way of functioning is different, they use different working methods with the recipients of services and benefits, they have a different philosophy of acting, they also manage an institution and finances in a different way. "One of the most distinctive differences is that civil organizations are sensitive to real needs and almost immediately react to their emergence, undertaking actions towards solving the problem" (Hola 2011, p. 195). The cooperation of local government bodies and non-governmental organizations should be based on four basic principles (Guć 2001, p. 135). Partnership, defined by equal, based on clear principles cooperation of both parties in the pursuit to the development and welfare of the social community. Openness, which should be based on an easy and equal access to the cooperation with local government of all interested social entities, meeting only defined substantive criteria, towards which no other restrictions are used. Transparency, which should be interpreted as the clarity of procedures and principles of establishing cooperation and the right to participate social partners in decision-making. And finally the diversity of forms of cooperation and social participation, not limited to only granting donations.

\section{Non-governmental organizations and the market}

The market is the place to verify the suitability of particular goods and services and also the best way to increase the socio-economic effectiveness, however, although it is the condition of sustainable development, it is not equally efficient in all areas of human activity and it is not able to solve many problems emerging in the economy (Golinowska 1994a, p. 38) in particular with reference to the social sphere, for which the free and universality of services is appropriate, that is the lack of connection of a benefit with the payment, and further the profit (cf. Kozłowski 1998, p. 28-29).

Market enterprises are not naturally established to implement goals of a social nature. Their task is to satisfy material needs expressed in money. They are only interested in such needs that can be translated into developing the economic surplus. The market, which being based on private capital, aspires to maximize the profit, is not interested in the implementation of tasks of a strictly social nature. It will work in this area only when the social activity will be accompanied by the economic benefit. 
This deficiency of the market can be efficiently restricted by non-governmental organizations, whose manner of functioning is different, but many of which do not distance themselves from market rules. The majority of them base their existence on the resources from running the business activity and treat, as a goal of their operation, both, maximizing the profit and satisfying social needs at the highest level. Most of them also internalize the principles of social responsibility and emphasize the quality of relations with the external environment (cf. ŁośTomiak, Dalecka 2013).

The coexistence of both groups of entities in the socio-economic system of the state gives the chance for the effective realization of tasks. More and more common becomes the identification of mutual relations through the prism of a donator-beneficiary system, where enterprises are treated as a source of obtaining financial resources by non-profit institutions, which defines a oneway interdependence. It begins to dominate the opinion that both, the first and second type of the participants of the market game takes the equal position and cooperating - successfully implements its statutory tasks and gains an individual profit.

Commercial entities associate bigger and bigger hopes with non-governmental organizations. The cooperation with them simply pays. Due to it, they strengthen or create their positive image and enhance the position of own brand. They use knowledge, competences and familiarity of the environment and social needs, and also the channels of the distribution of goods and operating strategies.

Intersectoral collaboration can concern both, assistance benefits, implementing philanthropic tasks, in accordance with the idea of social responsibility, and economic activities, i.e. purchasing from the entities of social economy work, products and services.

\section{Intersectoral cooperation - the chance for self-development and development of the region}

The opportunity for the flourishing of the sector of non-profit organizations, as for all other market or public entities, becomes competition on the one hand, and cooperation, on the other. Competition is "the element of selection and searching for the most successful and the most efficient forms of solving problems and creating valuable values" (Toczyński 1996, p. 21). With respect to undertaken issues, it can refer to the activity of non-governmental entities, local administration and central institutions. Then, it is possible to compete for civil activity and trust, which can decide about the existence of particular entities 
on the market. Moreover, measurable benefits can be brought by competing for customers, tasks or funds only between non-governmental organizations. Furthermore, competition can concern the internal organization of nongovernmental organizations. It is necessary to remember that competition that can be recognized as the source of undoubted benefits for each, including protecting and ensuring people, activity, it can also bring unexpected negative results, among others, obscure the proper purpose of undertaken actions, the primacy of the social over particular interest. However, at the lowest level of social activities, which concerns the functioning of the family, neighbouring ties and often non-governmental organizations, a more proper accepted form should be cooperation.

Despite various difficulties the third sector deals with, it is also necessary to pay attention to its institutional and professional maturity as well as to the development of the law system in this scope and strong anchoring in the realities of market economy, equally towards the first and second sector and not in opposition, or optionally to both of them. The basis becomes the "professionalism" of the sector, which "with reference to a non-government organization, "professional" should mean, firstly, reliable; secondly - reliable and responsible; thirdly - reliable and open to people; and fourthly - reliable and approaching social problems in an unconventional, innovative way" (Dudkiewicz 2002, p. 280-281).

As a chance for the local development, the cooperation of local government structures and non-governmental ones, including the market, requires formalization and professionalization of both parties, which can bring measurable benefits, but can also be the source of tension and threats. Undoubtedly the advantages (Hryniewiecka 2004, p. 9) of such interaction can be a more effective work and better recognition of needs, which can be translated into the increase of the quality of services and enlarging the range of possibilities. It is also better coordination of undertaken projects, more efficient attempts to obtain public resources for running the activity, and also greater economy as the effect of regulation by customer market and sponsorship market. Among the opportunities it is possible to mention standardization of services, enhancement of position and the use of the third sector potential. Also the increase of employment and diversification of the sources of financing measures. Besides, activating and organizing local communities among the entities of a nongovernmental sector. The promoted cooperation can also bring particular threats and problems. Non-profit organizations, for intensification and formalization of contacts, must pay with the loss of spontaneity and restriction of independence 
of action. They must face the increasing bureaucracy. However, the threat can become the excessive professionalization, resulting in the decrease of interest in some kinds of needs, being able to lead to clientelism and blurring natural social ties. The formalization of measures can increase the cost of the sector, which can contribute to the decrease of the efficiency of its action.

\section{Conclusions}

It is hoped that undertaking more frequently, although insufficiently, cooperation of local government structures and the entities of civil society and the market, will take a proper direction. There will be the elimination of barriers (Gliński 1998, p. 18-27) restricting interaction. Clear procedures of cooperation and financing will be developed, based on properly formed legal regulations. The issue of identifying local social needs will be solved. The psychological and ambitious issues as well as awareness and educational problems will be clarified. It is necessary to hope that, despite the discussion supporting the development of civil society, politicians, still without trust to non-governmental organizations (Golinowska 1994a, p. 34) will begin to treat the third sector as the right one for the implementation of the purposes for the socio-economic and cultural development. It would be appropriate when the entities of non-government sector developed standards of their measures, with reference to both, the services provided outside, in a particular sphere, and those that regulate the internal organization of the sector (Boczon 2001b, p. 82). External standards of services should be the outcome of the experiences of all, acting in a particular area, in a given time and place, entities. In contrast, the internal regulations of the sector would allow to define clearly who is who in the third sector and would help build the representation of the non-governmental sector, which is characterized by a common interest and trustworthiness. The process of creating the identity and representation of the sector requires high culture and time as well as must have an authentic bottom-up nature in order to avoid manipulation.

\section{Summary}

\section{Intersectoral collaboration - cooperation or competition?}

The paper presented the separation of the economy into three sectors. The mutual relations between sectors were described, with a particular reference to the cooperation of non-governmental organizations and public institutions. The role of non-profit institutions in the proper and efficient implementation of the social 
function of the state was highlighted. The attention was paid to the importance of non-governmental organizations in the system of social security as well as to the significance of tasks undertaken in cooperation of public administration. The assessment of the quality of the conducted cooperation was conducted and the necessity of deepening it for mutual benefits, and the benefits of beneficiaries as well, was recommended.

Key words: non-governmental organizations, public sector, non-profit institutions, collaboration, cooperation.

\section{Streszczenie}

\section{Współpraca międzysektorowa - kooperacja czy konkurencja?}

$\mathrm{W}$ artykule zaprezentowano trójpodział gospodarki. Omówione zostały wzajemne relacje pomiędzy sektorami, ze szczególnym uwzględnieniem kooperacji organizacji pozarządowych i instytucji publicznych. Podkreślono rolę instytucji non-profit we właściwej i skutecznej realizacji funkcji społecznej państwa. Wskazano na wage organizacji pozarządowych $\mathrm{w}$ systemie bezpieczeństwa społecznego oraz rangę podejmowanych, wspólnie z administracją publiczną, działań. Dokonano oceny jakości realizowanej współpracy oraz wskazano na konieczność jej pogłębiania dla obopólnych korzyści, a także korzyści beneficjentów.

\section{Słowa}

kluczowe: organizacje pozarzadowe, sektor publiczny, instytucje non-profit, wspótpraca, kooperacja.

\section{References}

1. Boczoń J. (2001a), Organizacje pozarzadowe a standaryzacja ustug społecznych, w: M. Warowicki, Z. Woźniak (red.), Aktywność obywatelska w rozwoju społeczności lokalnej. Od komunikacji do wspótpracy, MUNICIPIUM, Warszawa.

2. Boczoń J. (2001b), Wspótpraca samorzadów lokalnych z organizacjami pozarządowymi w województwie pomorskim, w: J. Szymanczak, A. Chdyra (red.), Lokalna polityka społeczna, „Konferencje i Seminaria”, Nr 3(42)01, Biuletyn Biura Studiów i Ekspertyz Kancelarii Sejmu, Warszawa.

3. Dudkiewicz M. (2002), W sprawie profesjonalizmu organizacji pozarzadowych, 
w:P. Gliński, B. Lewenstein, A. Siciński (red.), Samoorganizacja społeczeństwa polskiego: trzeci sektor, IFiS PAN, Warszawa.

4. Gawroński S. (1999), Ochotnicy miłości bliźniego. Przewodnik po wolontariacie, Biblioteka „Więzi”, Warszawa.

5. Glinski P. (2003), Społeczeństwo obywatelskie w Polsce - problemy i nadzieje, w: E. Nycz (red.), Budowa lokalnego społeczeństwa obywatelskiego, Uniwersytet Opolski, Opole.

6. Gliński P. (1998), Wspótpraca organizacji pozarządowych z innymi sektorami, w: G. Skąpska (red.), Opiekuńczość czy solidarność? Obywatelskie formy wspótpracy $z$ władzami lokalnymi oraz pomocy społecznej, Wyd. Fundacja Międzynarodowe Centrum Rozwoju Demokracji, Kraków.

7. Golinowska S. (1994a), Polityka społeczna państwa w gospodarce rynkowej, PWN, Warszawa.

8. Golinowska S. (1994b), Nowa struktura instytucji sfery społecznej, Instytut Pracy i Spraw Socjalnych, Warszawa

9. Guć M. (2001), Wspótpraca samorządu z organizacjami pozarządowymi, jako szansa rozwoju społeczności lokalnej, w: M. Warowicki, Z. Woźniak (red.), Aktywność obywatelska w rozwoju społeczności lokalnej. Od komunikacji do wspótpracy, MUNICIPIUM, Warszawa.

10. Hola M. (2011), Wspótpraca gminy i powiatu z organizacjami pozarzadowymi, Interart, Warszawa.

11. Hryniewiecka A. (2004), Formalizacja działań organizacji społecznych, "Polityka Społeczna”, nr 2.

12. Hudson M. (1997), Bez zysków i strat. Sztuka kierowania organizacjami sektora pozarządowego, Fundusz Współpracy, Program Phare Dialog Społeczny, Warszawa.

13. Kafel T. (1997), Wykorzystanie metody analizy "partnerów” w monitoringu otoczenia organizacji non-profit, "Organizacja i Kierowanie”, nr 3.

14. Kantyka S. (2002), Organizacje pozarzadowe- partner samorządu, w: A. Frączkiewicz-Wronka (red.), Samorządowa polityka społeczna, Dom Wydawniczy Elipsa, Warszawa.

15. Kozłowski S.G. (1998), Systemy ekonomiczne. Analiza porównawcza, Wyd. UMCS, Lublin.

16. Krzyżanowska M. (2000), Finansowanie organizacji pozarzadowych, „Marketing i Rynek”, nr 1.

17. Leś E. (1998), Organizacje społeczne - studium porównawcze, Program Phare Dialog Społeczny, Warszawa.

18. Łoś-Tomiak A., Dalecka M. (2013), The concept of social responsibility in nongovernmental organizations, "Management", Vol. 17, No. 2.

19. Marciniak P. (1998), Lokalne partnerstwo samorzadu i organizacji pozarządowych, w: G. Skąpska (red.), Opiekuńczość czy solidarność? Obywatelskie formy wspótpracy z władzami lokalnymi oraz pomocy społecznej, 
Wyd. Międzynarodowe Centrum Rozwoju Demokracji Fundacja, Kraków.

20. Rymsza M. (2001a), Rola organizacji pozarzadowych w realizacji zadań lokalnej polityki społecznej samorzadu, w: J. Szymanczak, A. Chdyra (red.), Lokalna polityka społeczna, „Konferencje i Seminaria”, nr 3(42)01, Biuletyn Biura Studiów i Ekspertyz Kancelarii Sejmu, Warszawa.

21. Rymsza M. (2001b), Wspótdziatanie samorządu terytorialnego z organizacjami pozarządowymi, w: A. Grześkowiak (pod patronatem), Decentralizacja funkcji społecznych państwa, Dział Wydawniczy Kancelarii Senatu, Warszawa.

22. Schimanek T. (1997), Obywatelskie niepostuszeństwo w świetle kontrolnych $i$ innowacyjnych zadań trzeciego sektora, w: P. Frączak, Między lobbingiem a akcja bezpośrednia (metody działania obywateli), Stowarzyszenie Asocjacje , Zielone Brygady, Warszawa-Kraków.

23. Toczyński W. (1996), Rola organizacji pozarządowych w odrodzeniu społeczeństwa obywatelskiego, w: M. Załuska, J. Boczoń, (red.), Organizacje pozarządowe w społeczeństwie obywatelskim, Interart, Warszawa. 